\title{
Design, synthesis and antiproliferative activity of indole analogues of indanocine $\dagger$
}

Cite this: Med. Chem. Commun., 2013, 4, 1452

Received 16th July 2013

Accepted 16th September 2013

DOI: $10.1039 / c 3 m d 00200 d$

www.rsc.org/medchemcomm

\author{
Gemma A. Tunbridge, Joseph Oram and Lorenzo Caggiano*
}

The design and synthesis of a novel series of indole-analogues of indanocine is reported, together with their antiproliferative activity in the $\mathrm{NCl}$ 's panel of cancer cell lines. Indanocine displays potent activity against a wide range of cancer cell lines (mean $\mathrm{Gl}_{50}<20 \mathrm{nM}$ ), including drug-resistant cancer cell lines, and also inhibits the migration of metastatic cancer cells. A number of the described indole-analogues display a similar activity profile to indanocine, exhibiting potent antiproliferative activities in several cancer cell lines, and offer new leads for further development.

\section{Introduction}

Continuing our interest in compounds that interact with tubulin, ${ }^{\mathbf{1}, 2}$ we wished to investigate novel analogues of indanocine $\mathbf{1}$ (Fig. 1). Indanocine $\mathbf{1}$ is a substituted indanone that displays potent antiproliferative activity against tumour cell lines (mean $\mathrm{GI}_{50}<20 \mathrm{nM}$, the mean concentration to inhibit $50 \%$ cell growth against the National Cancer Institute's (NCI) panel of cancer cell lines), and is also active against multidrug resistant cell lines. ${ }^{3-5}$ Drug resistance can be due to several factors, including overexpression of the P-glycoprotein drug efflux pump, ${ }^{6}$ and studies have shown that although tumour cells which overexpress the $170 \mathrm{kD}$ P-glycoprotein are resistant to paclitaxel, they remain sensitive to indanocine $\mathbf{1 .}^{\mathbf{4}}$

Indanocine $\mathbf{1}$ is a potent microtubule-destabilizing agent and binds to the colchicine binding site of tubulin..$^{7-9}$ Recent reports have shown that indanocine reduces dynamic instability of microtubules at low concentrations and inhibits migration of metastatic cancer cells. ${ }^{\mathbf{1 0}}$ Therefore indanocine and associated analogues are of great interest as they not only have promise as potential chemotherapeutic agents, ${ }^{\mathbf{1 1}}$ but could also be used to prevent the spread of cancer through metastasis.

Various indanocine analogues have been previously reported, ${ }^{5,12-16}$ however, we wished to apply an approach previously reported by Hudlicky et al. in the design of pancratistatin analogue 3 (Fig. 1). ${ }^{17}$ Isolated by Pettit et al. ${ }^{18}$ pancratistatin 2 is a natural product which exhibits potent anticancer activity, ${ }^{19}$ and shows excellent promise as a therapeutic drug, particularly in brain cancers. ${ }^{20}$ Hudlicky et al. proposed that the indole

Medicinal Chemistry, Department of Pharmacy and Pharmacology, University of Bath, Claverton Down, Bath, BA2 7AY, UK. E-mail: l.caggiano@bath.ac.uk; Fax: +44 (0)1225 386114; Tel: +44 (0)1225 385709

$\dagger$ Electronic supplementary information (ESI) available: Experimental procedures, characterisation data, ${ }^{1} \mathrm{H}$ and ${ }^{13} \mathrm{C}$ NMR spectra, and COMPARE analyses of compounds 4c, 5c and 5g. See DOI: 10.1039/c3md00200d motif has similar steric and electronic properties to the 4hydroxy-benzo[1,3]dioxole group present in pancratistatin 2 (highlighted in bold, Fig. 1). ${ }^{17}$ In addition, the indole analogue 3 also retains the hydrogen-bonding pattern of the natural product 2 , believed to be important for potency.

Following this work, ${ }^{17}$ and the success of other indole-based inhibitors of tubulin polymerisation, ${ }^{21}$ we wished to investigate if the indole motif would also be a suitable bioisostere for the dimethoxyaniline group present in indanocine $\mathbf{1}$ (highlighted in bold, Fig. 2). We now describe the synthesis and antiproliferative activity of indole-analogues of indanocine (4 and 5) outlined in Fig. 3. We wished to investigate both the 5membered ring cyclic ketone (4, as found in indanocine $\mathbf{1})$ and the corresponding 6-membered ring core (5), since indanones ${ }^{5}$ and tetralones ${ }^{\mathbf{1 4 1 5 , 2 2}}$ of similar compounds were both found to be the most active. In addition, the effects of the $\mathrm{N}-\mathrm{H}$ hydrogen<smiles>COc1cc2c(c(N)c1OC)C(=O)/C(=C/c1cc(C)c(O)c(C)c1)C2</smiles><smiles>O=C1N[C@H]2[C@H](O)[C@H](O)[C@@H](O)[C@H](O)[C@H]2c2cc3c(c(O)c21)OCO3</smiles>

2, pancratistatin $^{18}$

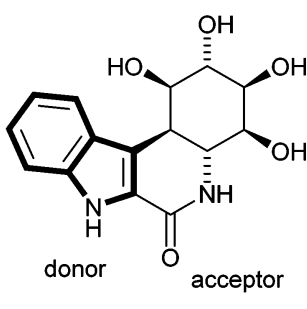

3, indole analogue ${ }^{17}$
Fig. 1 Structures of indanocine 1, pancratistatin 2 and an indole-analogue of pancratistatin 3. 


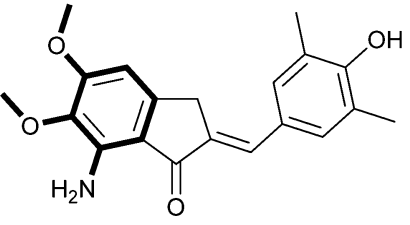

1 , indanocine

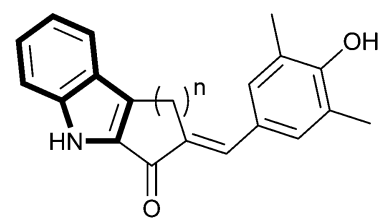

$\mathbf{4 c}, \mathrm{n}=1 ; \mathbf{5 c}, \mathrm{n}=2$; proposed indole analogues

Fig. 2 Proposed indole-analogues of indanocine.

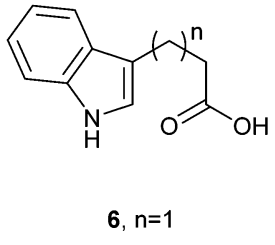

7, $n=2$

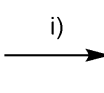<smiles>[R7]n1c2c(c3ccccc31)C(=O)CC2</smiles>

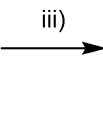

8, $n=1, \mathrm{R}^{1}=\mathrm{H}, 81 \%$

$9, n=2, R^{1}=H, 72 \%$

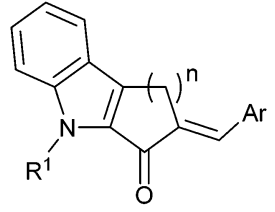

4a-h, $\mathrm{n}=1$

5a-h, n=2

Scheme 1 Synthesis of the indole-analogues $\mathbf{4 a - h}$ and $\mathbf{5 a - h}$. (i) PPA (6) or TFAA (7). (ii) KOH/Mel, acetone (iii) See Table 1.

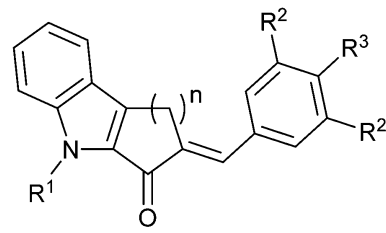

$4, n=1 ; 5, n=2 ;$ indole analogues

Fig. 3 Indole analogues of indanocine $\mathbf{4}$ and $\mathbf{5}$.

bonding interaction $\left(\mathrm{R}^{1}=\mathrm{H}, \mathbf{a}-\mathbf{d}\right.$ and $\left.\mathrm{R}^{1}=\mathbf{M e}, \mathbf{e}-\mathbf{h}\right)$ and various substituted aryl rings $\left(\mathrm{R}^{2}=\mathrm{Me}\right.$ or $\mathrm{OMe}$ and $\mathrm{R}^{3}=\mathrm{H}$ or $\left.\mathrm{OH}\right)$ were also investigated (see Table 1).

Table 1 Yields and NSC numbers of indole analogues 4 and 5 (Fig. 3)

\begin{tabular}{llllllll}
\hline Comp. & $\mathrm{R}^{1}$ & $\mathrm{R}^{2}$ & $\mathrm{R}^{3}$ & $n$ & Cond. $^{a}$ & Yield (\%) $^{2}$ & NSC $^{b}$ \\
\hline $\mathbf{4 a}$ & $\mathrm{H}$ & $\mathrm{Me}$ & $\mathrm{H}$ & 1 & $\mathrm{~A}$ & 72 & $\mathrm{~ns}$ \\
$\mathbf{4 b}$ & $\mathrm{H}$ & $\mathrm{OMe}$ & $\mathrm{H}$ & 1 & $\mathrm{~A}$ & 73 & $\mathrm{~ns}$ \\
$\mathbf{4 c}$ & $\mathrm{H}$ & $\mathrm{Me}$ & $\mathrm{OH}$ & 1 & $\mathrm{~B}$ & 61 & 756592 \\
$\mathbf{4 d}$ & $\mathrm{H}$ & $\mathrm{OMe}$ & $\mathrm{OH}$ & 1 & $\mathrm{~B}$ & 54 & 756591 \\
$\mathbf{4 e}$ & $\mathrm{Me}$ & $\mathrm{Me}$ & $\mathrm{H}$ & 1 & $\mathrm{~A}$ & 45 & $\mathrm{~ns}$ \\
$\mathbf{4 f}$ & $\mathrm{Me}$ & $\mathrm{OMe}$ & $\mathrm{H}$ & 1 & $\mathrm{~A}$ & 12 & - \\
$\mathbf{4 g}$ & $\mathrm{Me}$ & $\mathrm{Me}$ & $\mathrm{OH}$ & 1 & $\mathrm{~B}$ & 3 & $\mathrm{~ns}$ \\
$\mathbf{4 h}$ & $\mathrm{Me}$ & $\mathrm{OMe}$ & $\mathrm{OH}$ & 1 & $\mathrm{~B}$ & 49 & $\mathrm{~ns}$ \\
$\mathbf{5 a}$ & $\mathrm{H}$ & $\mathrm{Me}$ & $\mathrm{H}$ & 2 & $\mathrm{C}$ & 29 & 756584 \\
$\mathbf{5 b}$ & $\mathrm{H}$ & $\mathrm{OMe}$ & $\mathrm{H}$ & 2 & $\mathrm{C}$ & 47 & 756585 \\
$\mathbf{5 c}$ & $\mathrm{H}$ & $\mathrm{Me}$ & $\mathrm{OH}$ & 2 & $\mathrm{D}$ & 21 & 756586 \\
$\mathbf{5 d}$ & $\mathrm{H}$ & $\mathrm{OMe}$ & $\mathrm{OH}$ & 2 & $\mathrm{D}$ & 33 & 756587 \\
$\mathbf{5 e}$ & $\mathrm{Me}$ & $\mathrm{Me}$ & $\mathrm{H}$ & 2 & $\mathrm{C}$ & 55 & 756588 \\
$\mathbf{5 f}$ & $\mathrm{Me}$ & $\mathrm{OMe}$ & $\mathrm{H}$ & 2 & $\mathrm{C}$ & 26 & 756589 \\
$\mathbf{5 g}$ & $\mathrm{Me}$ & $\mathrm{Me}$ & $\mathrm{OH}$ & 2 & $\mathrm{D}$ & 11 & 756590 \\
$\mathbf{5 h}$ & $\mathrm{Me}$ & $\mathrm{OMe}$ & $\mathrm{OH}$ & 2 & $\mathrm{D}$ & - & -
\end{tabular}

${ }^{a}$ Reaction conditions for Step (iii) in Scheme 1: $\mathrm{A}=\mathrm{KOH} / \mathrm{EtOH}, \mathrm{rt} ;{ }^{25,26} \mathrm{~B}$ $=\mathrm{KOH} /$ methoxyethanol, $120{ }^{\circ} \mathrm{C} ; \mathrm{C}=\mathrm{LiOH} / \mathrm{H}_{2} \mathrm{O} / \mathrm{EtOH}^{27}{ }^{27} \mathrm{D}=\mathrm{BF}_{3} \cdot \mathrm{OEt}_{2}$, dioxane. ${ }^{28} b$ NCI's National Service Center (NSC) number; ns $=$ not selected by the NCI.

\section{Results and discussion}

The synthesis of the analogues is shown in Scheme 1 and the yields and conditions in Table 1. Commercially available 3indolepropionic acid (6) or 3-indolebutyric acid (7) were treated with PPA $^{23}$ or TFAA, respectively, to afford the corresponding cyclic ketone $8(81 \%)$ or $\mathbf{9}(72 \%$, Step i, Scheme 1$)$.

Following previously reported procedures, ${ }^{23,24}$ methylation of the indole nitrogen was readily achieved using $\mathrm{KOH} /$ MeI, affording the N-Me derivatives 10 (95\%) and 11 (92\%, Step ii). Finally, the cyclic ketones 8-11 underwent ClaisenSchmidt condensation with the required aldehyde in the presence of base or Lewis acid to give the indole-analogues 4a-h and 5a-g, as shown in Scheme 1 (Step iii) and Table 1. Owing to capricious results, several reaction conditions were used in this transformation, ${ }^{25-28}$ which are described in the ESI. $\dagger$

Only the $E$-isomers were obtained from the Claisen-Schmidt condensation reaction, as identified by the characteristic downfield shift of the $\mathrm{COC}=\mathrm{CH}$ proton, due to a deshielding effect caused by diamagnetic anisotropy by the $\mathrm{C}=\mathrm{O}$ which is cis to this proton, as previously noted. ${ }^{29}$ This assignment was confirmed by key NOESY interactions (see ESI $\dagger$ compounds $\mathbf{5 c}$ and $\mathbf{5 g}$ ) and is consistent with observations made with this reaction in similar substrates which also gave the $E$ isomers. ${ }^{13-15,22,30}$

4-Hydroxy-3,5-dimethylbenzaldehyde and the corresponding 3,5-dimethoxy derivative, syringaldehyde, were investigated as although the former aldehyde gave the substitution pattern observed in indanocine $\left(R^{2}=\right.$ Me, Fig. 3$)$, the latter is readily available and inexpensive.

Nine compounds were selected for one-dose preliminary in vitro evaluation at $10 \mu \mathrm{M}$ by the NCI (those with NSC numbers in Table 1). Five of these compounds (4c, 5a-c and 
Table 2 Growth inhibition of indanocine $\mathbf{1}$ and selected analogues $\mathbf{4 c}, \mathbf{5 c}$ and $\mathbf{5 g}$ in the $\mathrm{NCl} 60$ panel of cancer cell lines

\begin{tabular}{|c|c|c|c|c|c|}
\hline \multirow[b]{2}{*}{ Panel } & \multirow[b]{2}{*}{ Cell line } & \multicolumn{4}{|c|}{$\mathrm{GI}_{50}(\mu \mathrm{M})^{a}$} \\
\hline & & 1 & $4 c$ & $5 c$ & $5 g$ \\
\hline \multirow[t]{6}{*}{ Leukemia } & CCRF-CEM & 0.01 & 2.18 & 0.36 & 0.74 \\
\hline & HL-60(TB) & 0.01 & $0.34^{b}$ & $0.21^{b}$ & $0.34^{b}$ \\
\hline & $\mathrm{K}-562$ & 0.01 & $0.33^{b}$ & $0.32^{b}$ & $0.33^{b}$ \\
\hline & MOLT-4 & 0.01 & 6.01 & 0.56 & 0.80 \\
\hline & RPMI-8226 & 0.01 & 0.67 & 0.47 & 0.76 \\
\hline & SR & 0.01 & 0.39 & 0.22 & 0.34 \\
\hline Non-Small & A549/ATCC & 0.01 & $1.58^{b}$ & $0.55^{b}$ & $0.74^{b}$ \\
\hline \multirow[t]{8}{*}{ Cell Lung } & EKVX & 0.01 & 2.59 & 3.38 & 4.84 \\
\hline & HOP-62 & 0.02 & 0.65 & 0.65 & 0.72 \\
\hline & HOP-92 & 100 & 7.47 & 0.78 & 6.56 \\
\hline & NCI-H226 & 3.98 & 9.60 & 3.29 & 4.38 \\
\hline & NCI-H23 & 0.01 & $1.79^{b}$ & $0.65^{b}$ & $2.53^{b}$ \\
\hline & NCI-H322M & 0.01 & 10.4 & 0.53 & 2.73 \\
\hline & NCI-H460 & 0.01 & 0.42 & 0.41 & 0.39 \\
\hline & NCI-H522 & 0.01 & 0.09 & 0.13 & 0.14 \\
\hline \multirow[t]{7}{*}{ Colon } & COLO 205 & 5.01 & 19.5 & 14.2 & 22.9 \\
\hline & HCC-2998 & 2.00 & 7.49 & 2.21 & 3.61 \\
\hline & HCT-116 & 0.01 & 0.50 & 0.44 & 0.39 \\
\hline & НCT-15 & 0.01 & 0.56 & 0.42 & 0.51 \\
\hline & HT29 & 2.51 & 15.8 & 4.32 & 4.18 \\
\hline & KM12 & 0.01 & 0.46 & 0.39 & 0.45 \\
\hline & SW-620 & 0.01 & 0.41 & 0.41 & 0.43 \\
\hline \multirow[t]{6}{*}{$C N S$} & SF-268 & 0.01 & 0.86 & 0.73 & 0.72 \\
\hline & SF-295 & 0.06 & 2.78 & 1.88 & 1.48 \\
\hline & SF-539 & 0.01 & 0.55 & 0.32 & 0.70 \\
\hline & SNB-19 & 0.01 & 0.71 & 0.58 & 0.63 \\
\hline & SNB-75 & - & 0.29 & 0.29 & 0.41 \\
\hline & U251 & 0.02 & 1.12 & 0.43 & 0.54 \\
\hline \multirow[t]{9}{*}{ Melanoma } & LOX IMVI & 0.01 & 0.69 & 0.76 & 0.70 \\
\hline & MALME-3M & - & $0.31^{b}$ & 0.38 & 0.45 \\
\hline & M14 & 0.01 & 0.41 & 0.34 & 0.39 \\
\hline & MDA-MB-435 & 0.01 & 0.16 & 0.12 & 0.16 \\
\hline & SK-MEL-2 & 1.00 & 0.40 & 0.32 & 0.33 \\
\hline & SK-MEL-28 & 1.00 & $0.73^{b}$ & 0.74 & 0.64 \\
\hline & SK-MEL-5 & 0.01 & 0.39 & 0.33 & 0.41 \\
\hline & UACC-257 & 100 & 26.1 & 0.37 & 5.83 \\
\hline & UACC-62 & 0.01 & 4.57 & 0.42 & 0.41 \\
\hline \multirow[t]{7}{*}{ Ovarian } & IGROV1 & 0.04 & 3.54 & 0.74 & 1.59 \\
\hline & OVCAR-3 & 0.01 & 0.51 & 0.33 & 0.35 \\
\hline & OVCAR-4 & 7.94 & 10.2 & 1.35 & 3.87 \\
\hline & OVCAR-5 & 0.63 & 11.1 & 2.35 & 5.10 \\
\hline & OVCAR-8 & 0.01 & 0.99 & 0.53 & 0.92 \\
\hline & NCI/ADR-RES & 0.01 & 0.35 & 0.31 & 0.34 \\
\hline & SK-OV-3 & 0.01 & 0.73 & 0.47 & 1.52 \\
\hline \multirow[t]{8}{*}{ Renal } & $786-0$ & 0.01 & 5.96 & 0.88 & 3.25 \\
\hline & A498 & 7.94 & 4.86 & 1.83 & 3.39 \\
\hline & ACHN & 0.06 & - & 0.77 & 0.83 \\
\hline & CAKI-1 & 3.98 & 1.40 & 0.61 & 0.84 \\
\hline & RXF 393 & 0.03 & 1.43 & 0.52 & 1.08 \\
\hline & SN12C & 0.01 & 0.62 & 0.62 & 0.72 \\
\hline & TK-10 & 79.4 & $6.27^{b}$ & $0.54^{b}$ & $1.08^{b}$ \\
\hline & UO-31 & 0.08 & 0.32 & 0.45 & 0.73 \\
\hline \multirow[t]{2}{*}{ Prostate } & PC-3 & 0.01 & 3.57 & 1.06 & 2.49 \\
\hline & DU-145 & 0.01 & 2.05 & 0.54 & 1.85 \\
\hline \multirow{2}{*}{ Breast } & MCF7 & 0.01 & 0.70 & 0.35 & 0.37 \\
\hline & MDA-MB-231/ATCC & 0.01 & 3.19 & 1.06 & 1.06 \\
\hline
\end{tabular}

Table 2 (Contd.)

\begin{tabular}{llllll}
\hline \multirow{2}{*}{ Panel } & \multicolumn{5}{c}{$\mathrm{GI}_{50}(\mu \mathrm{M})^{a}$} \\
\cline { 3 - 6 } & $\mathbf{1}$ & $\mathbf{4 c}$ & $\mathbf{5 c}$ & $\mathbf{5 g}$ \\
\hline & Cell line & - & 0.55 & 0.38 & 0.73 \\
HS 578T & 10 & - & 0.53 & 2.84 \\
BT-549 & 100 & 12.6 & 0.74 & 2.06 \\
T-47D & - & 2.43 & 0.29 & 0.31 \\
MDA-MB-468 & &
\end{tabular}

$\mathbf{5 g})$ were selected for further examination at five-doses. Three of these five analogues were selected for a repeat screen $(\mathbf{4 c}, \mathbf{5 c}$ and $\mathbf{5 g}$ ) and the results obtained are shown in Table 2, as the average of these two runs, together with indanocine 1 for comparison.

Indanocine 1 is extremely potent cell growth inhibitor, displaying $10 \mathrm{nM}$ activity against many of the cell lines examined by the NCI. Although our analogues display decreased activities, they retain useful levels of potency in the low sub-micromolar range.

From Table 2, it is apparent that certain cells types appear particularly sensitive to the indole-analogues, such as Non-Small Cell Lung NCI-H522 cell line ( $\left.\mathrm{GI}_{50}=93 \mathrm{nM}, 4 \mathrm{c}\right)$ and Melanoma MDA-MB- 435 cells $\left(\mathrm{GI}_{50}=120 \mathrm{nM}, \mathbf{5 c}\right)$. Of particular note is that all three analogues display sub-micromolar growth inhibition against the multi-drug resistant NCI/ADR-RES cell line. Other cell lines, however, appear more resilient to the analogues which are also reflected in indanocine $\mathbf{1}$, such as the Melanoma cell line UACC-257 $\left(\mathrm{GI}_{50}=100 \mu \mathrm{M}, \mathbf{1}\right.$, and $\left.26.1 \mu \mathrm{M}, \mathbf{4 c}\right)$. Interestingly, the cyclohexanone $\mathrm{N}-\mathrm{H}$ derivative $5 \mathrm{c}$ still retains activity in this cell line $\left(\mathrm{GI}_{50}=370 \mathrm{nM}\right)$. Likewise similar discrepancies with compound $\mathbf{5 c}$ are also observed in Renal TK10 and Breast T-47D cell lines.

Of the compounds synthesized and examined in this study, the most active antiproliferative analogues are those most similar in structure to indanocine, as predicted in Fig. 2. They all possess a benzylidene with a hydroxyl group $\left(\mathrm{R}^{3}\right)$, flanked either side with methyl groups $\left(\mathrm{R}^{2}\right)$; methoxy groups at $\mathrm{R}^{2}$ were detrimental to activity. These observations are consistent with previously established SAR around the benzylidene ring ${ }^{5}$ and calculations used to identify important pharmacophoric points for indanocine. ${ }^{31}$

Methylation of the indole nitrogen $\left(\mathrm{R}^{1}\right)$ was tolerated in the 6-membered ring series (5), as both the $\mathrm{N}-\mathrm{H}$ (5c) and $\mathrm{N}-\mathrm{Me} \mathrm{(5g)}$ analogues displayed good activities (Table 2). Although the 5membered ring $\mathrm{N}-\mathrm{H}$ analogue $\mathbf{4 c}$ was active, the corresponding $\mathrm{N}-\mathrm{Me}$ derivative $\mathbf{4} \mathbf{g}$ was not selected by the NCI, so a comparison cannot be made. These results suggest that although changes to the aryl group are not tolerated, indole $\mathrm{N}$-substitution is and demonstrate that further modifications around the indole ring, as observed in many indole-based tubulin inhibitors, ${ }^{21}$ should be investigated in future. 
From the final three analogues, the cyclopentanone derivative $\mathbf{4 c}$ was selected by the NCI for consideration by the Biological Evaluation Committee and has been classified as a tubulin binder. COMPARE analysis ${ }^{32,33}$ of the lead compound 4c using the standard algorithm with Synthetic Compounds gave the strongest correlation (0.795) with centaureidin (NSC 106969), a natural product isolated from the tropical plant Polymnia fruticosa which exhibits antiproliferative activity through the inhibition of tubulin polymerisation. ${ }^{34,35}$ Other compounds identified by the COMPARE algorithm included several combretastatin derivatives (see ESI $\dagger$ ), which are also tubulin-binding agents and, like indanocine 1, similarly interact with the colchicine binding site and inhibits tubulin polymerisation. ${ }^{36}$ Of particular note is that the lead compound $4 \mathbf{c}$ also displayed good correlation (0.646, rank 26) with indanocine 1 (NSC 698666). Of interest is that although combretastatin derivatives were also observed in the COMPARE analyses of both compounds $\mathbf{5 c}$ and $\mathbf{5 g}$, only the cyclohexanone $\mathrm{N}-\mathrm{Me}$ analogue $\mathbf{5 g}$ showed any significant correlation with indanocine $\mathbf{1}(0.593$, rank 108$)$ as the cyclohexanone $\mathrm{N}-\mathrm{H}$ derivative $5 \mathbf{c}$ displayed poor correlation (0.426, rank 707).

\section{Conclusions}

In summary, we report that the indole group is an effective bioisostere for the dimethoxyaniline motif present in indanocine 1 and describe the synthesis of several indole-based analogues, in either two or three steps from commercially available materials. Several of these compounds were selected for evaluation by the National Cancer Institute (NCI) and analysis using the COMPARE algorithm show that our strategy was successful and that we have identified a novel class of compounds which, like indanocine $\mathbf{1}$, interact with tubulin and display potent antiproliferative activity against various cancer cell lines including drug-resistant cells.

Although "indolocine" $\mathbf{4 c}$ is less potent than indanocine 1, the indole group offers a versatile platform to generate further derivatives with more desirable physicochemical properties and target enhanced potency and selectivity. Such compounds could find potential as novel chemotherapeutic agents to combat cancer or prevent its spread by inhibiting the migration of metastatic cancer cells and will be investigated and reported in due course.

\section{Acknowledgements}

We wish to thank Dr Timothy J. Woodman and Dr Anneke Lubben (University of Bath) for their assistance with the NMR and mass spectra, respectively. We also wish to thank Dr Pauline J. Wood (University of Bath) for preliminary cell work. We are extremely grateful to the National Cancer Institute (NCI) for conducting the in vitro testing and the University of Bath for providing a studentship for GAT. We also wish to acknowledge RCUK and the University of Bath for the fellowship to LC.

\section{Notes and references}

1 A. Ciupa, N. J. Griffiths, S. K. Light, P. J. Wood and L. Caggiano, Med. Chem. Commun., 2011, 2, 1011-1015.

2 A. Ciupa, P. A. De Bank, M. F. Mahon, P. J. Wood and L. Caggiano, Med. Chem. Commun., 2013, 4, 956-961.

3 D. A. Carson, H. C. Shih, H. B. Cottam and L. Leoni, US Pat., 6,162,810, 2000.

4 L. M. Leoni, E. Hamel, D. Genini, H. Shih, C. J. Carrera, H. B. Cottam and D. A. Carson, J. Natl. Cancer Inst., 2000, 92, 217-224.

5 H. C. Shih, L. Deng, C. J. Carrera, S. Adachi, H. B. Cottam and D. A. Carson, Bioorg. Med. Chem. Lett., 2000, 10, 487-490.

6 A. H. Schinkel and J. W. Jonker, Adv. Drug Delivery Rev., 2003, 55, 3-29.

7 X. H. Hua, D. Genini, R. Gussio, R. Tawatao, H. Shih, T. J. Kipps, D. A. Carson and L. M. Leoni, Cancer Res., 2001, 61, 7248-7254.

8 L. Das, S. Gupta, D. Dasgupta, A. Poddar, M. E. Janik and B. Bhattacharyya, Biochemistry, 2009, 48, 1628-1635.

9 Y. Lu, J. J. Chen, M. Xiao, W. Li and D. D. Miller, Pharm. Res., 2012, 29, 2943-2971.

10 S. Kapoor and D. Panda, Biochem. Pharmacol., 2012, 83, 1495-1506.

11 P. Giannakakou, D. Sackett and T. Fojo, J. Natl. Cancer Inst., 2000, 92, 182-183.

12 L. M. Leoni, H. C. Shih, L. Deng, C. Tuey, G. Walter, D. A. Carson and H. B. Cottam, Biochem. Pharmacol., 1998, 55, 1105-1111.

13 T. M. Al-Nakib, T. Lóránd, A. Földesi and R. Varghese, Med. Princ. Pract., 2001, 10, 191-196.

14 B. Hallgas, Z. Dobos, E. Ösz, F. Hollósy, R. E. Schwab, E. Z. Szabó, D. Erős, M. Idei, G. Kéri and T. Lóránd, J. Chromatogr., B: Anal. Technol. Biomed. Life Sci., 2005, 819, 283-291.

15 B. Hallgas, Z. Dobos, A. Agócs, M. Idei, G. Kéri, T. Loránd and G. Mészáros, J. Chromatogr., B: Anal. Technol. Biomed. Life Sci., 2007, 856, 148-155.

16 L. Huang, C. Lu, Y. Sun, F. Mao, Z. Luo, T. Su, H. Jiang, W. Shan and X. Li, J. Med. Chem., 2012, 55, 8483-8492.

17 U. Rinner, T. Hudlicky, H. Gordon and G. R. Pettit, Angew. Chem., Int. Ed., 2004, 43, 5342-5346.

18 G. R. Pettit, V. Gaddamidi, G. M. Cragg, D. L. Herald and Y. Sagawa, J. Chem. Soc., Chem. Commun., 1984, 1693-1694.

19 A. Kornienko and A. Evidente, Chem. Rev., 2008, 108, 19822014.

20 G. Van Goietsenoven, V. Mathieu, F. Lefranc, A. Kornienko, A. Evidente and R. Kiss, Med. Res. Rev., 2013, 33, 439-455.

21 S. A. Patil, R. Patil and D. D. Miller, Future Med. Chem., 2012, 4, 2085-2115.

22 J. R. Dimmock, N. M. Kandepu, A. J. Nazarali, T. P. Kowalchuk, N. Motaganahalli, J. W. Quail, P. A. Mykytiuk, G. F. Audette, L. Prasad, P. Perjési, T. M. Allen, C. L. Santos, J. Szydlowski, E. De Clercq and J. Balzarini, J. Med. Chem., 1999, 42, 1358-1366.

23 F. Maertens, A. Van den Bogaert, F. Compernolle and G. J. Hoornaert, Eur. J. Org. Chem., 2004, 4648-4656. 
24 K. E. Judd, M. F. Mahon and L. Caggiano, Synthesis, 2009, 2809-2817.

25 A. Hassner and N. H. Cromwell, J. Am. Chem. Soc., 1958, 80, 893-900.

26 B. W. Day, V. N. Korotchenko and W. M. Tsang, Patent WO 2010108058-A2, 2010.

27 S. Bhagat, R. Sharma, D. M. Sawant, L. Sharma and A. K. Chakraborti, J. Mol. Catal. A: Chem., 2006, 244, 2024.

28 T. Narender, K. Venkateswarlu, B. Vishnu Nayak and S. Sarkar, Tetrahedron Lett., 2011, 52, 5794-5798.

29 D. N. Kevill, E. D. Weiler and N. H. Cromwell, J. Org. Chem., 1964, 29, 1276-1278.

30 P. Perjési, T. Nusser, G. Tarczay and P. Sohár, J. Mol. Struct., 1999, 479, 13-19.
31 T. L. Nguyen, C. McGrath, A. R. Hermone, J. C. Burnett, D. W. Zaharevitz, B. W. Day, P. Wipf, E. Hamel and R. Gussio, J. Med. Chem., 2005, 48, 6107-6116.

32 K. D. Paull, C. M. Lin, L. Malspeis and E. Hamel, Cancer Res., 1992, 52, 3892-3900.

33 M. R. Boyd and K. D. Paull, Drug Dev. Res., 1995, 34, 91-109. 34 J. A. Beutler, J. H. Cardellina II, C. M. Lin, E. Hamel, G. M. Cragg and M. R. Boyd, Bioorg. Med. Chem. Lett., 1993, 3, 581-584.

35 J. A. Beutler, E. Hamel, A. J. Vlietinck, A. Haemers, P. Rajan, J. N. Roitman, J. H. Cardellina II and M. R. Boyd, J. Med. Chem., 1998, 41, 2333-2338.

36 M. Marrelli, F. Conforti, G. A. Statti, X. Cachet, S. Michel, F. Tillequin and F. Menichini, Curr. Med. Chem., 2011, 18, 3035-3081. 